Nataša Lah

\title{
How Style Became Famous and Irrelevant at the Same Time
}

Keywords: historical style, stylistic codification, objectual style in Modernism, stylistic classification, stylistic appearance, stylistic expressivity, erasing the style borders

DOI: $10.4312 /$ ars.9.2.215-230

What is style? What are the recognizable characteristics of style in the history of visual arts? These questions instigated many theoretical debates which, until this day, failed to yield the unified and generally accepted definition of style. Such an unstable position of style in visuality can become intelligible if we consider the significance of historical turns that caused the irreversible demarcations between the theoretical status and the social role of style within art history, in a period after 1764. That was the year when Johann Joachim Winckelmann detached stylistics from rhetoric. Consequently, he expanded the sphere of style's jurisdiction into the history of art, anchoring style within a temporal dimension in order to enable the stylistic analysis of historical periods in art.

In this respect, it is entirely neglected that style acquired its disciplinary autonomy almost simultaneously with the start of schism within that very autonomy. Specifically, this was the start of a huge historical theoretical debate concerning a definition of what we consider to be "the recognizable characteristics" of artwork and therefore of style as well.

On one side, this conflict was led by "classicists", undoubtedly including Winckelmann as well. On the other side there were romanticists, amongst whom we find encyclopaedist (what an irony) Denis Diderot. While writing his Salons from 1759 to 1781, Diderot subordinated a previous paradigm of "the norm of form" - that was attuned with the paradigm of epoch - to the idea of individual artist's norm.

Hitherto, form mirrored the given systems, whether notional (èidos) as in Middle Ages, or visible and obvious (morfé) as in Antiquity and Renaissance. Intellectuals belonging to the then new tendency advocated the form that evaded a centuries-old task of description, all to the advantage of individual unrepeatableness. From this point on, the idea of individual expression as prevailing against the creation's extrinsic value became irrevocably rooted, announcing the Modernism. 
In other words, if over the centuries visual form could be caught in the net of something which we rightfully designated as the style of epoch (regardless the variations of spatial-temporal differences within it), then the actual visual form could be grasped, surprisingly late, in regard to the status of activity which was differentiated from the other skills as "fine" or "visual" art. ${ }^{1}$ Such activity, which rather late came to be named or acknowledged as something different and irreducible to anything else, previously followed the spirit of epoch as the status "skill". Further on, this epochal spirit was mirrored in the realizations of more or less skilful masters, always as a formal feedback in regard to the content.

Communicating, due its own preciousness, the (mainly) elitist messages of commissioners, art - just like any other language - created its own and diverse sorts of grammar and semiotics, the ranges of synonymous differences, stylistically polished. The specific differences between artworks which have stylistically marked the epoch have been regarded to be more or less acceptable departures from the norm. However, by affirming the idea of individual expression, art - like a disobedient child - deflected from a world of "parental" protection exerted by church, state, king or emperor into a world of free creation. At that point, the stylistic departure acquired the status of norm.

\section{From the disciplinary autonomy to the autonomy of stylistic departure}

As late as the 1930s, Julius von Schlosser observed the importance of opposition which has risen in the second half of the $18^{\text {th }}$ century between individual form and the common language of epoch. Hence, the stylistic analysis acquired the disciplinary autonomy during the 1770s, as the art of previous epochs was normed by a respective

1 Though art started becoming independent from a group of other manual skills as late as the $16^{\text {th }}$ century, concretely through the endeavours of British philosopher Francis Bacon - who classified skills into the activities of reason (science), memory (history) and imagination (poetry) - music and painting remained in a subgroup of skills which are pleasant, in comparison to the practical ones. Somewhat later, Portuguese architect, sculptor and painter Francisco de Holanda used the expression boas artes for the first time. Soon enough, the baroque conflict between traditional objectivism and the subjectivist idea of "taste", which selects and defines, lit the first spark of idea which will be developed to its utter limits by Modernism, as an entirely new stylistic paradigm of pure formalism, independent of any objectivity pertaining to the epochal views. The credible document of the mentioned baroque conflict are the works by French architects François Blondel (Le Cours d'architecture dating from 1675) and Claude Perrault (L'Ordonnance des cinq espèces de colonnes est l'expression la plus achevée de la théorie dating from 1683). Perrault's conception of subjectivism became a generally accepted aesthetic conception. The birth of aesthetics (Alexander Gottlieb Baumgarten, Aesthetica, 1750) was a birth of the criticism of taste, since "after all, a philosopher is a man among other men". Not earlier than the objectivistic swing of enlightenment, theory returned to the sources of the historical development of style, partly through the works of art historian J. J. Winckelmann and partly through aesthetics such as those of Kant and Hegel. Besides, Hegel's encyclopaedic "cathedral" of spirit created a prototype of stable relations between form and content, the prototype that will meet its first, real and very serious alternative only with the arrival of Modernism. 
dominating epochal paradigm and thus by the habits and expectations of audience regarding the classification, in accord with the contexts of usage, genera and genres. The antique style, speaking most broadly, was a conventional, visible system of form possessing the physioplastic characteristics. The style of medieval art was again a conventional, yet symbolic system with ideoplastic characteristics. The illusion reached its ideoplastic pinnacle in the Renaissance by manifesting its own peculiar "mimetism", imposed by the depths of spatial infiniteness.

In this context, we should mention that Giorgio Vasari acted as a kind of predecessor to Winckelmann. Justly enough, Vasari arouses interest to the present day, as he focused at a detail as the indicator of writing, despite using a modestly scoped comparative material, namely the example of the "development" of Florentine painting from the medieval times to the time of Vasari's contemporaries, which remained the subject of many studies to the present day. It's even more interesting to notice how Ernst H. Gombrich warned Vasari's critics of a fact that Vasari wasn't (and couldn't have been) aware of a function which culture ascribed to the painting and plastic art belonging to the time he wrote about. In part, a metatheoretical insight of such a kind was unnecessary, because it was in no way provoked. The normative and norming epochs of the pre-modern development of history, culture and therefore art as well, were necessarily codifying. The old view of style, as the developmental system of codified norms, understood by and of itself, announced the modern epoch significantly later, in the period of early Romanticism, when codification was rejected to the advantage of interpretation and classification.

With its ideas of free creation, early Romanticism initiated - and the schism of Paris Salon definitely stabilized - another and alternative, until this day confusingly non-differentiated role of style in the development of both modern and postmodern epochs. Whether we admit it or not, two mutually cancelling paradigms begun interfering as the irreducible theoretical focal points within the understanding of the history of art. ${ }^{2}$ On one hand there was Paris Salon, which originated in 1725 under the patronage of Academy of Fine Arts (Académie des Beaux-Arts) in Paris. Until the Second World War, Paris Salon supported the tradition of conservative, academically oriented "official" art, which processed the historical and religious themes, descriptive landscapes, conventional portraits and narrative genres in general. On the other hand, Salon des Refusés was held for the first time in 1863 for the reasons connoted

2 Interference can be observed in stylistic terms such as "the style of French academism", referring to a hybrid style that equates neoclassicism and romanticism. From a modernist perspective this destroys the credibility of Bouguereau - who was very famous in his own time. On the other hand Cézanne, his authentic style departing from the original Impressionism and announcing the arrival of Cubism, is being codified as a post-impressionist. In both cases, the codification is based on sustaining the parameters of stylistic development. 
in its very title. In 1884 Salon des Refusés gave rise to French Society of Visual Artists (Société Nationale des Beaux-Arts), thus forming Salon des indépendants which, with no jury and no awards, paved the way for the events which presented new trends, heterogeneous conceptions and avant-gardes. The critics who advocated this new art stemmed mainly from the literary milieus and wrote negatively about the official Salon's activity, with the aim of popularizing the art of Realism and Impressionism amongst the wider audience. This was reported in detail by Venturi in his now already forgotten History of Art Criticism. By negating the laws of existent stylistic languages, these critics built hypotheses and interpretations regarding the new styles, generated the reasons for their survival and sometimes for their incomparable self-sufficiency. It was a sort of "art-historical hermeneutics", a phrase that was much later on applied by Oskar Bätschmann in reference to the nature of similar procedures in his "instructions for the interpretation of art".

On the other hand, art historians remained favourably disposed towards Paris Salon which was lead by Academy of Fine Arts. They wrote texts for the catalogues of Salon's exhibitions, participated in juries which selected artworks, awarded prizes and altogether supported the official and institutionally acknowledged course of academism.

In this way, which was substantially backed by the profession, style remained disciplinary anchored in a temporal dimension, which enabled the further and unobstructed application of stylistic analysis, based on differences between the historical periods and epochs, in continuity. ${ }^{3}$ Besides, such codifying stylistic analysis of historical periods can be applied only when researching the production which preceded the 1770s or, alternatively, the production rising parallel and past to avantgardes in subsequent historical periods. It cannot be employed in regard to the time when the traditional givens were eluded, that is to Modernism.

\section{The stylistic imperative of the nondisturbance of obviousness}

The functions and meanings of the historical paradigms, their contexts, genera and genres, have been replaced by an artist, with his self-sufficient awareness regarding what an artwork is, how it should look and which (changeable) styles it should conjecture. Inasmuch, more than all the previous epochs, Modernism affirmed the

3 Until this day, most of university courses on art history carry titles based on the ideas concerning the developmental paradigms of "the stylistic unity of chronological whole". This is especially difficult to operationalize when teaching and comprehending the periods of the $19^{\text {th }}$ and $20^{\text {th }}$ centuries. Moreover, the schism within the stylistic unity, which occurred during the second half of the $18^{\text {th }}$ century, usually remains submerged and unnoticed at the margins of Modern History. 
obviousness of visuality, eluding all of the semantic, functional, utilitarian, narrative and symbolic burdens of the earlier periods. Following some strange inertia and, partially, due to the task's weight, the old model of stylistic analysis was also applied when analysing the artworks of high Modernism and avant-gardes. Timely, very wisely and justifiably, formalists (in a word, the staunchest mainstays of Modernism) announced the intrinsic significance of form or - in other words - affirmed the status of the unhindered obviousness of visual form. ${ }^{4}$ However, in that case, what has remained of style? Actually, the most essential part: the emphasised expressivity of the characteristics of artwork, at a level of its obviousness. The artwork's style, that is the objectual style, has replaced the paradigm of historical style. (Figure 1)

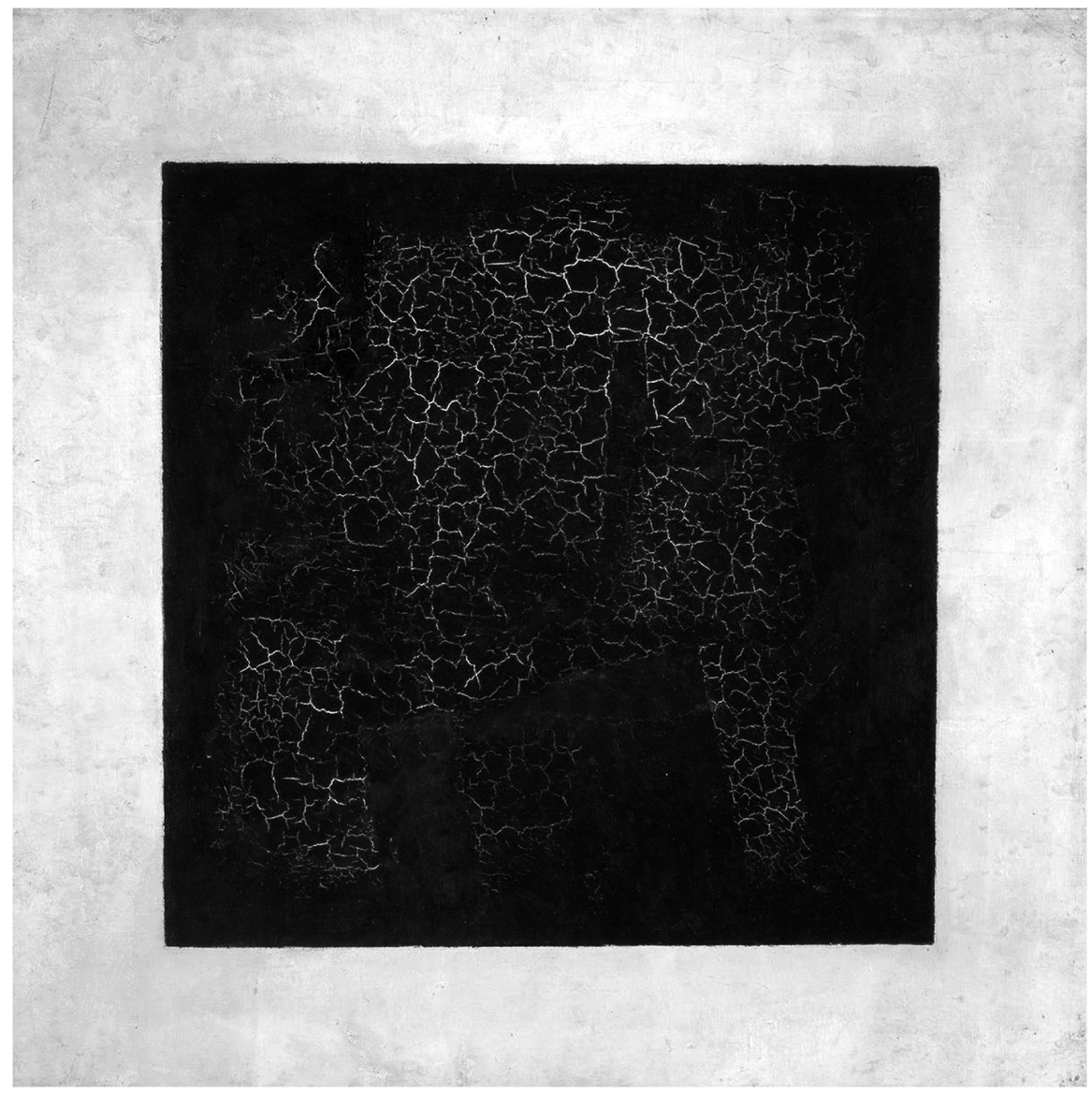

Figure 1: Kazimir Malevich, Black Square, 1915, oil on canvas, Tretyakov Gallery, Moscow.

4 In this context "l'art pour l'art" movement is but an earlier, programmatically limited equivalent of the reduction of artwork's meaning and content to the advantage of self-sufficiency of the represented. 
In this regard, only the traditionalists know how confusing can be the approach according to which the most important characteristic of Malevich's Black Square (Figure 1) is actually a black square on a white ground. Only the theorists of formalism and the true lovers of aesthetics and the idea of Modernism know how fascinating is that the most prominent characteristic of Malevich's Black Square is actually this monochromatic scene of a black geometrical figure on a white ground, which is nothing more than that which it represents. The matter in hand is that we have to understand how a depiction, rather than the widely conceived "reality", has been reduced to a supremacy of figure and not to the subsequently added and unreliably interpreted Malevich's "sensibility". Because, the style of this artwork (and its dominant characteristics of emphasised expressivity) is the pure supremacy of geometric figure, nothing more and nothing less. Here, style is discernible and therefore based on the visual expression of the self-sufficient, individual obviousness of what is being represented.

As already indicated, codification - as one of the qualifications of stylistic characteristics - begun losing its credibility in the period of early Romanticism. By separating the views on art during the historical conflict between "the profession" and "the critics" of Paris Salon, it finally lost its foothold, at least in that part of production which ranked high at the top-lists valuing the art production of the second half of the $19^{\text {th }}$ and the first half of the $20^{\text {th }}$ century, all the way down to postmodernism, when the situation completely changed. During the period of Modernism, style was looking for another approach, differing from everything that preceded it. Therefore, the comparative tracking of stressed expressive characteristics became based on the psychological factors and the factors concerning observer's education, observer's inclination to mainstream conformism or else to the subversive politics of modernist elitism in art.

In other words, this is a matter of a complex system of perception, reception and selection of the point of view (contextualization). Briefly, the listed factors can be referred to as the characteristics of the selection of that which will be deemed as the obviously recognizable. After the selection comes the classification, that is, a possibility of comparability and extractability, based on discerning the style's expressive characteristics. This procedure is founded on a comparison of artwork's emphasised expressive visual aspects in relation to a congenial group of phenomena.

In the period of Modernism, the individual theoretical effort - conditioned by the observer's psychological and educational, as well as by the social, cultural and political attitudes - replaced the professional patterns of comparativedevelopmental codification, opening doors to interdisciplinarity and intertextuality, 
along with all their advantages and risks. Introduced by modern art, based exclusively on the visual obviousness of artwork and supported by the theories, thus understood conception was composed of the visually expressivity, that is to say of the facture and the authorial "writing", along with the visual appearance or, in other words, the total material stageability. Inasmuch, the only relatively stable stylistic codification of artwork in modern art is possible as a result of the extractability of artwork from a congenial group of phenomena, based on visual expressivity and appearance.

Art theorist Amy Dempsey proposed a rather concrete argument for grouping the artworks belonging to modern art (within the analysis relating to a period from 1860 to 1990), clearly separating style trends from other and different phenomena in the art of the mentioned period. Dempsey argues that all the art productions whose basic intention was "to create a total living environment for the modern world" - whether manifested as top design achievements (for instance: Arts and Crafts or Bauhaus), architecture (for instance: Chicago School or Vienna Secession) or political / cultural ideologies (for instance: Hungarian activism, socialist Realism, Situationist International or Fluxus) - are the art schools. The schools aspired to change the environment or the way of life, they were public and directed at the general public. The art productions aspiring to "utter" the emphasised semantic values or the individually conceptual features are classified by Dempsey as a group of art movements (for instance: Dada, Surrealism, Existentialist art, happening, performance, Conceptualism, Neo-Avantgarde ...). However, the group of artistic productions including a number of visual trends which, through the formal language of obviousness, that is to say, through the exclusively phenomenal artwork's characteristics have "demonstrated" the forms, always anew changing their statement and the rules of appearance - leaning solely against the artwork's obvious aspects - are classified by Dempsey as the style trends. We believe Dempsey is justified in apostrophising a link connecting the notion of "style" with the artwork's visual characteristics. More precisely, her arguments support the argument proposed in this article, which claims that we can speak of style only in cases when the artwork's stressed expressive characteristics are obvious.

In order to exemplify the meaning of stylistically enhanced expressivity which is based on obviousness, we shall take a look at four paradigmatic modernist works by various authors, created in a period between 1909 and 1945, all linked by their respective usage of the minimal stylistic units of form.

These are: Shimmering Substance by Jackson Pollock (1946), Airplane Flying by Kazimir Malevich (1915), Horta de Ebro by Pablo Picasso (1909) and The Treachery 
of Images by René Magritte (1928-1929). Their stylistic codification respectively manifest at the level of appearance as: dots, lines and stains (Pollock), lines and figures (Malevich), figures and forms (Picasso), form and text (Magritte). At the level of expressivity, with Pollock we discern painterly automatism. With Malevich it is geometrism and with Picasso it is polyperspectivism, while in Magritte's work the appearance is based on combining form and text, whereby expressivity is displaced from the realm of obviousness to the field of semantics. Further, concerning the semantic expressivity, Magritte's artwork moves out from the stylistic discourse into the art movements (concretely: Surrealism). Pollock, Malevich and Picasso remain in the field of obviousness, both at the level of expressivity and the level of appearance, on which basis their artworks belong respectively to the following styles: dripping painting within the framework of American Expressionism or the so called Second Avantgarde (Shimmering Substance), Suprematism (Airplane Flying) and Proto-Cubism (Horta de Ebro).

\section{Objectual-stylistic and historical-stylistic (re)contextualization}

Modernism introduced another stylistic novelty which can be conditionally termed as the objectual-stylistic recontextualization. Duchamp's objet trouvé - "Belle Haleine" (Figure 2), originated from a bottle of perfume and an author's portrait/ photograph. This Duchamp's work possesses a complex history and the stratified interpretative levels. According to Arturo Schwarz, one of the most controversial aspects of this Duchamp's work is a fact that it is being mirrored in the multiple recontextualizations of two "found objects", of which one is endowed with a utilitarian function and a popular social status and is publicly accessible (a bottle of perfume can be bought by anybody). The other has a representational function and is entirely private, following the origin of its accessibility (the portrait photograph of the actual author, possessed and used by himself). Through their integration, a newly created object enters the sphere of the objectual domain of visual art, acquiring an elite status. Its accessibility is articulated institutionally, while its function is articulated within the aesthetical self-sufficiency. Therefore, obvious re-contextualization becomes the artwork's recognizable expressive characteristic. The author starts with assembling the samples of objectual obviousness, whose integration perpetuates them into a new "item" or "object", which is again objectual. (Figure 2) 


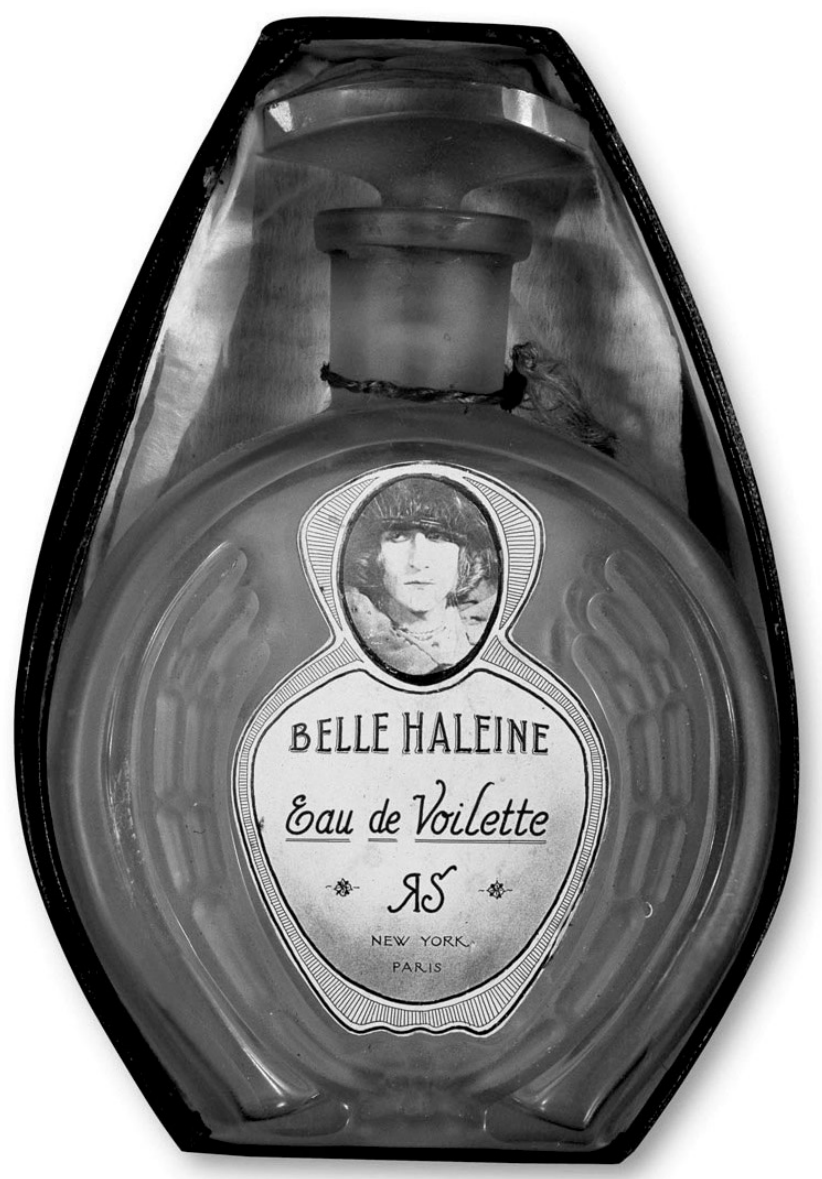

Figure 2: Marcel Duchamp, "Belle Haleine (Beautiful Breath)" Perfume Bottle, with a photograph of Rose Sélavy (alias Marcel Duchamp) by Man Ray pasted on, 1921. ${ }^{5}$

The objectual-stylistic recontextualization is followed by the historical-stylistic recontextualization which, rather generally, could be referred to as a quotation or more precisely an ekphrasis within a frame of the same medium. This is a comprehensive phenomenon of the interpretative strategy of historical sources in Modernism, which was the subject of extensive studies by Oto Bihalji Merin and Vera Horvat Pintarić. The historical-stylistic recontextualization which took hold in the works of many modern artists, including Brancusi (Cycladic plastic art), Picasso (Africa), Beaudin (Easter Island), Moore (Egypt), Klee (Peru) ... is interpreted by Merin as the new art forms which consciously tie up the modern artist's strength of intellect with archaic

5 Vir: http://www.gazette-drouot.com/static/magazine_ventes_aux_encheres/enchere_collection_ saintlaurent_berge.html?lang=0 
imagination, all with the aim of achieving the contemporary mythical wholeness (Bihalji Merin, 1962, 49).

In a subtitle to a chapter titled Svjedok $u$ slici (transl. note: Witness in Image) of the homonymous book, Horvat Pintarić borrows a William Rubin's syntagma elective affinity (Horvat Pintarić, 2001, 35) - in order to define the historical-stylistic recontextualization in modern art, by answering a question: "Off all the influences in our century, why has the one exerted by tribal art been the strongest?"

Naturally, the answer cannot be unequivocal. Still, following the line of our argument which claims that the persistence of the idea of style is connected to the material characteristics of the visible and is based on obviousness - where the artwork's objectual-stylistic (re)contextualization is manifested as readymade, while the historical-stylistic one is demonstrated as a quotation - we believe that the newly risen languages of Modernism aimed at restoring the mythical-narrative aspects of historical resources, as much as they aspired to deepen the visual-constitutional possibilities of representation, taking into consideration the historical experience (of objects, subjects, intersubjectivity...) In both cases, the artwork's recognizable expressive characteristic yields a newly created value, by (re)contextualizing the already-seen as the alreadyexistent, which is but an equivalent of mimetic art and a sort of nostalgia for premodern times. This is a way to revive the already existent within the new readings, which makes these artworks modern, simultaneously announcing Postmodernism (especially the idea of "the death of the author") and the time in which reading of the represented will become imposed to obviousness, throwing the idea of style into a dustbin (or a museum) of history.

\section{Conclusion}

The effects of the subversive language of Modernism in relation to the previously dominant epochal styles have subjected the untouchable status of Modern History man's erudition, previously defined by "the norm of form", to the temptations of the untouchable creative subject. A modernist does not renounce the form, but becomes the norm himself. In this way modernist elevates "authorship" to the elite level of stylistic language, which reached its pinnacle during the 1960s, while its descending trajectory was announced with the rise of anti-painting, regardless of the latter disappearing within the metaphysical (see Meanders by Julije Knifer) or the physical extensions (see Spatials by Lucio Fontana) of its given spatial frames.

Nevertheless, this created a new elitism of the modernist style, which Niklas Luhmann interpreted as a new regulator of perception, irrespective of a fact that the 
modernist style opposed the cannon, norm and conventions of the previous epoch's language. This is simply the matter of audience becoming divided. On one hand there are the "professional" observers of artwork, capable of perceiving the artwork's relation to the congenial epoch's artworks, that is to say, observers capable of "recognizing" style (which, according to Luhmann is the observing of the second order). On the other hand there are those other, "amateur observers" (captivated within the observing of the first order), who are incapable of accepting the subversiveness of individual style in relation to the dominant style.

The style of modernists has announced the "death" of the author in the very moment of author's complete affirmation. Moreover, by shifting the focus from the artwork towards the author, it opened a space for the institutional theory of art, the idea of the art world and the comprehensive problem of receptive practices. The characteristics of style in Modernism became the characteristics of authors, eventually dispersing into the intertextual and interdisciplinary space of the countless readings of the same. In the last stage, this lead to the development of the reductionist and auto-reflexive aesthetics of Modernism, by announcing the theoretical object which confronted the concept with the idea of obviousness, and therefore also with any sort of stylistic norming (or normativity).

In short, conceptual art is a successor of a phenomenon which we recognized as the physical transformation of image. It is also the vanguard of Process and Antiform art. In this cycle, the artwork got transformed from an objectual and object phenomenon into a spatial-temporal situation, process or event. By popularizing that is by attacking - the elitist aspects of modernist art, artwork, in association with "art institutions", became an interactive part of a context of both world and culture. Further on, by its definition, activism presumes the reinterpretation of art in relation to the cultural stereotypes of sex, gender, race, ethnicity... while Neo-expressionism subversively questions the social reaction to the obviousness of loneliness, deformity, perversion and the culture of accident, including the artwork's function in the analysis of visual text (the semantics of image). The hybrid art theory is concerned with video art as the theory of simulationism. It treats the art of re-representation as the theory of appropriation and considers the art of the so called "historical reenactment" as the theory of post-appropriation art. These are followed by the rise of performative event, most closely connected to the idea/forms of experiential (re) constructions. Again, an artist is not concerned with performing or representing, but with context and atmosphere wherein the act of performing is played out.

Even under such circumstances we do not speak of obviousness, but of the theory of the semantic non-falsifiability of statement. These were the circumstances around 
forming the definition of relational aesthetics and postproduction, where the artist is positioned as a "catalyst" of relational rapports between art and society, instead of being at the centre. Is this The End of the History of $\operatorname{Art}^{6}$ (as we know it)? Our answer to this question is negative. This is simply a crisis of the faltered normative certainty on which the tradition of art history mainly rested. Seemingly innocent questions What was style and what is style? should point at the possible crisis of disciplinary borders, at the actual place of dissent between the normative standards of stylistic obviousness and the theoretical footholds of other and different approaches to the "reading" of visuality.

By erasing the proportions of stylistic obviousness, the borders of visual space change as well. How will the borders restructure in future times? Are we entering an unlimited sphere? These questions are certainly not the matter of style, as much as they are the matter of artistic, critical, theoretical and scientific attitude.

\section{References}

Altieri, C., Style as the Man: What Wittgenstein Offers for Speculating on Expressive Activity. Journal of Aesthetics and Art Criticism, 46, 1987, pp. 177-192.

Barthes, R., La mort de l'Auteur, Le bruissement de la langue, Paris 1984, pp. 61-67.

Bätschmann, O., Uvod u povijesnoumjetničku hermenutiku: Interpretacija slika, Zagreb 2004.

Belting, H., The End of the History of Art?, History and Theory, 27 (2), 1988, pp. 188199.

Bihalji Merin, O., Prodori moderne umjetnosti. Utopija nove stvarnosti, Beograd 1962.

Bourriaud, N., Relational Aesthetics, Dijon 2002.

Burioni, M., Die Renaissance der Architekten: Profession und Souveränität des Baukünstlers in Giorgi Vasaris Viten, Berlin 2007.

Butler, J., Excitable Speech : A Politics of the Performative, New York, London 1997.

Carney, J. D., Individual Style, Journal of Aesthetics and Art Criticism, 49 (1), 1991, pp. 15-22.

Carroll, N., Danto, Style, and Intention, The Journal of Aesthetic and Art Criticism, 1995, 53 (3). pp. 251-257.

Danto, A., The Artworld, The Journal of Philosophy, American Philosophical Association Eastern Division Sixty-First Annual meeting (Oct. 15, 1964) 61(19), 1964, pp. 571-584.

6 A syntagma according to the title of book by H. Belting: The End of the History of Art? (1988). 
Dempsey, A., Styles, Schools and Movements. The Essential Encyclopaedic Guide to Modern Art, London 2002.

Dickie, G., Aesthetics, An Introduction, Cambridge 1971.

Diderot, D., Essais sur la peinture: Salons de 1759, 1761, 1763, Paris 1984.

Diderot, D., Héros et martyrs : Salons de 1769, 1771, 1781, Paris 1995.

Diderot, D., Ruines et paysages : Salons de 1767, Paris 1995.

Diderot, D., Salon de 1765, Paris 1984.

Elsner, J., Style, Critical Terms for Art History, (eds. Nelson, R.S., Shiff, R.), Chicago 2003.

Gombrich, E. H., The Renaissance Conception of Artistic Progress and its Consequences, Norm and Form. Studies in the art of Renaissance, London, 1966, pp. 1-10, 137-40.

Gombrich, E. H., Vasari's "Lives" and Cicero's "Brutus", Journal of the Warburg \& Courtauld Institutes, 23 (3/4), 1960, pp. 309-311.

Goodman, N., The Status of Style in: Ways of Worldmaking, Indianapolis 1978. pp. 23-41.

Hadjinicolaou, N., Style as visual ideology, Modern art and modernism : a critical anthology (eds. Frascina F., Harrison, C.), London 1982, pp. 244-246.

Horvat Pintarić, V., Svjedok u slici. Nove figure za nove stvarnosti u eri moderne. Zagreb 2001.

Lang, B. (ed.), The Concept of Style, Philadelphia 1979.

Luhmann, N., "Das Kunstwerk und die Selbstreproduktion der Kunst" in: Stil. Geschichten und Funktionen eines kulturwissenschaftlichen Diskurselements, (eds. Gumbrecht, H. U., Pfeiffer, K. L.) Frankfurt am Mein. 1986, pp. 623-626.

Rubin, W., Primitivism in the $20^{\text {th }}$ Century Art : The Museum of Modern Art, New York 1984, pp. 10-11, 24-25.

Schapiro, M., Theory and Philosophy of Art: Style, Artist, and Society. New York 1994.

Schwarz, A., The Complete Works of Marcel Duchamp, New York 1970.

Struken, M., Cartwrigt, L., Practices of Looking, New York 2001.

Vasari, G., Le vite de' più eccellenti architetti, pittori et scultori italiani, da Cimabue insino a' tempi nostri, Florenze 1550.

Venturi, L., History of art criticism, New York 1936.

Von Schlosser, J., "Stilgeschichte" und "Sprachgeschichte" der bildenden Kunst : ein Rückblick, München 1935. 
Wartofsky, M. W., The Livelines of Aesthetics, The Journal of Aesthetics and Art Criticism 46 (spec. Issue, Analytic Aesthetics), 1987, pp. 211-218.

Winckelmann, J. J., Geschichte der Kunst des Alterthums, Leipzig 1764. 
Nataša Lah

\section{Kako je slog postal slaven in hkrati nepomemben}

Ključne besede: zgodovinski slog, stilna kodifikacija, predmetni slog v modernizmu, slogovna klasifikacija, slogovna izraznost, brisanje slogovnih zamejitev

Članek se ukvarja s teoretskim vprašanjem statusa stila in stilnih opredelitev v likovni umetnosti. Izpostavlja, da je na področju umetnostne zgodovine stilistika dobila avtonomno vrednost v poznem 18. stoletju, ko jo je J. J. Winckelmann oddvojil od retorike in razširil tudi na področje zgodovine umetnosti ter izoblikoval koncept historičnih slogov. V istem času so se pod vplivom zgodnje romantike v Evropi pojavile nasprotne težnje, ki so poudarjale individualni značaj umetnosti. Tako so vzporedno s teoretskim konceptom historičnih slogov romantiki tlakovali pot modernizmu in spodkopavali apliciranje nove stilistične metodologije, ki si je prizadevala za kodifikacijo stila. Napetosti med »romantiki« in »klasicisti«, so vrhunec dosegle v shizmi pariškega Salona in pojavu različnih novih trendov, heterogenih konceptov in avantgard. Koncept zgodovinskega sloga pa so v temeljih zamajali izzivi 20. stoletja, saj ga ni bilo mogoče aplicirati na raznoliko umetniško ustvarjalnost $\mathrm{v}$ obdobju modernizma, ko sta $\mathrm{v}$ ospredje stopili poudarjena izraznost kot ključna lastnost umetniškega dela in njegova avtentičnost na ravni likovnega. $V$ tem kontekstu poskuša članek pokazati, kako lahko po obdobju modernizma o stilu v likovni umetnosti razpravljamo izključno na ravni očitno izraženih likovnih lastnosti umetniškega dela in kako je kodifikacija, ki sledi načelu časovnega »sidranja« znotraj kulturnega konteksta, za obdobje modernizma sporna in nezadostna stilistična strategija. 
Nataša Lah

\section{How Style Became Famous and Irrelevant at the Same Time}

Keywords: historical style, stylistic codification, objectual style in Modernism, stylistic classification, stylistic appearance, stylistic expressivity, erasing the style borders

The article is concerned with the theoretical issue of the status of style in visual arts, aiming to demonstrate that - within art history - stylistics acquired its disciplinary autonomy in the late $18^{\text {th }}$ century when, J. J. Winckelmann was the first to detach stylistics from rhetoric, thus expanding the field of stylistic competence to the history of art. It was also the time when, under the influence of early Romanticism, the entirely opposite tendencies originated, those of the emphasized individuation of art. Therefore, parallel to the birth of theoretical notion of "the styles of the eras", romanticists not only paved the way for Modernism, but also thwarted the application of a newly risen stylistic methodology concerned with the cultural codification of style. The disagreement between the "classicists", and "romanticists", eventually culminated in the schism of the Paris Salon and the emergence of a wide range of new trends, heterogeneous conceptions and avant-garde movement, all in a very short space of time. The concept of "the style of epoch" has been staggered by the challenges of the $20^{\text {th }}$ century. The function of culture within the stylistic characteristics of the $19^{\text {th }}$ century art production was appropriated by artists, whose artwork acquired total objectual autonomy. The cultural and stylistic codification of of historical periods conceived in the $18^{\text {th }}$ century could no longer be applied to the heterogeneous art produced during the Modernist era. By affirming the obviousness of the visual, Modernism eluded all the semantic, functional, utilitarian, narrative and symbolic burdens of earlier periods. This article endeavours to show how, subsequent to the epoch of Modernism, style can be discussed exclusively at a level of the apparent expressed features of an artwork. Codification which follows the principle of temporal "anchoring" in the cultural context of the Modernits era of Modernism remains both risky and ineffective stylistic strategy. 